\title{
Jurist-Diction
}

Volume 4 No. 1, Januari 2021

\section{Pengaturan Pajak Pariwisata Dalam Rangka Kebijakan Indonesian Tourism}

\author{
Verdi Hadyan Marsiyuda \\ verdimarsiyuda@gmail.com \\ Universitas Airlangga
}

How to cite:

Verdi Hadyan Marsiyuda, 'Pengaturan Pajak Pariwisata Dalam Rangka Kebijakan Indonesian Tourism' (2021) Vol. 4 No. 1 Jurist-Diction.

Histori artikel:

Submit 12 November 2020; Diterima 09 Desember 2020; Diterbitkan 5 Januari 2021.

DOI:

10.20473/jd.v4i1.24308

p-ISSN: $2721-8392$

e-ISSN: $2655-8297$

\section{Abstract}

One of the efforts made to carry out national development is derived from tax revenues. More than $80 \%$ of the Republic of Indonesia's state revenue comes from taxes. Tourism Tax is a source of tax revenue sourced from the regency/city tax. Regional Tax that is regulated by Law Number 28 Of 2009 regulates the sources of regional revenue which is the full authority of the region. Indonesian tourism ranks third in foreign exchange earnings after oil and gas commodities and palm oil, because the government is collecting taxes on the tourism sector so that it affects the increasing industry of the tourism sector. This can have a direct effect on business and the economy that can be measured by labor wage income in the tourism sector, as well as an increase in regional income. With the growth of the tourism sector, it is also very related to the development of infrastructure which is very important, because if there is no appropriate infrastructure.

Keywords: Tax Tourism; Law Enforcement; Indonesian Tourism.

\begin{abstract}
Abstrak
Salah satu upaya yang dilakukan untuk melakukan pembangunan nasioanl yaitu berasal dari penerimaan pajak. Lebih dari $80 \%$ penerimaan Negara Republik Indonesia berasal dari pajak. Pajak Pariwisata merupakan sumber penerimaan pajak yang bersumber dari pajak kabupaten/kota Pajak Daerah yang diatur Undang-Undang Nomor 28 Tahun 2009 mengatur sumber-sumber penerimaan daerah yang merupakan kewenangan penuh oleh daerah. Pariwisata Indonesia menempati urutan ke tiga dalam penerimaan devisa setelah komoditi minyak dan gas bumi beserta kelapa sawit, karena pemerintahan melakukan pemungutan pajak pada sektor pariwisata supaya berpengaruh terhadap meningkatnya industri sektor pariwisata. Hal tersebut dapat menghasilkan efek secara langsung pada bisnis serta ekonomi yang dapat diukur dari pendapatan upah tenaga kerja pada sektor pariwisata, serta meningktanya suatu pendapatan daerah. Dengan terjadinya pertumbuhan sektor pariwisata, maka sangat terkait juga dengan adanya pengembangan infrastruktur yang hal itu menjadi sangat penting, karena jika tidak adanya infrastruktur yang sesuai, maka akses untuk menuju tempat pariwisata akan rumit.

Kata Kunci: Pajak Pariwisata; Penegekan Hukum; Indonesian Tourism.
\end{abstract}




\section{Pendahuluan}

Pajak menjadi salah satu sumber dana pemerintah untuk melakukan pembangunan yang terus dilaksakan baik pemerintah pusat maupun pemerintah daerah. Sebagai instrument bangsa, pajak bersifat memaksa, maka jelas uang yang dikumpulkan dari pajak akan dikembalikan kepada rakyat dalam bentuk pembangunan sarana umum yang dibiayai melalui pajak oleh pemerintah itu sendiri. Pasal 1 ayat (1) Undang-Undang Nomor 28 Tahun 2007 Tentang Ketentuan Umum dan Tata Cara Perpajakan, menjelaskan pajak merupakan kontribusi wajib kepada negara yang terutang oleh orang pribadi atau badan yang bersifat memaksa berdasarkan Undang-Undang dengan tidak mendapatkan imbalan secara langsung dan digunakan untuk keperluan negara bagi sebesar-besarnya kemakmuran rakyat.

Pemungutan pajak sangat erat kaitannya dengan fungsi pajak sebagai salah satu sumber penerimaan negara. Pajak yang dipungut akan memiliki empat fungsi untuk pemerintah yang melaksanakan pemungutan pajak, maka empat fungsi tersebut yakni fungsi budgetair atau fungsi penerimaan negara, regulerend (regulasi) atau fungsi mengatur, fungsi demokrasi, dan fungsi redistribusi. ${ }^{1}$ Berlandaskan jenis pajak, maka pajak di Indonesia dikelompokan berdasarkan golongannya atau cara pemungutannya, berdasarkan sifatnya dan juga berdasarkan pemungutannya.

Pajak berdasarkan golongannya atau cara pemungutannya dibedakan menjadi dua, yakni pajak langsung dan pajak tidak langsung. Pajak langsung merupakan pajak yang bebannya harus ditanggung sendiri oleh Wajib Pajak yang bersangkutan dan tidak dapat diahlikan kepada orang lain maupun dikenakan secara berulangulang pada waktu tertentu. Pajak tidak langsung merupakan pajak yang bebannya dapat diahlikan ke pihak lain serta hanya dikenakan atas hal-hal tertentu ataupun peristiwa-peristiwa tertentu saja. ${ }^{2}$ Kemudian ada jenis pajak yang digolongkan berdasarkan sifatnya, yakni pajak subjektif dan pajak objektif. Pajak subjektif merupakan pajak yang berpangkal pada subjeknya, pengenaan pajak subjektif memperhatikan keadaan maupun kondisi pribadi dari Wajib Pajak. Pajak Objektif

\footnotetext{
1 Marihot Pahala Siahaan, Hukum Pajak Elementer (Graha Ilmu 2010).[43].

2 Erly Suandy, Hukum Pajak (Salemba Empat 2008).[38].
} 
merupakan pajak yang berpangkal pada pajak objeknya tanpa ada memperhatikan kondisi maupun keadaan dari Wajib Pajak. Setalah beberapa jenis tersebut, jenis pajak selanjutnya merupakan jenis pajak yang pengelompokannya berdasarkan pada lembaga pemungutannya yang terbagi menjadi dua, yakni pajak pusat yang dikelola oleh pemeritah pusat dan pajak daerah yang dikelola oleh pemerintah daerah, baik tingkat daerah ataupun kabupaten/kota.

Pengelolaan pajak ditinjau dari tarif yang dikenakan, dan mempunyai tarif yang berbeda-beda. Berdasarkan tarif pajak tersebut, pajak dapat dibedakan menjadi empat, yakni tarif tetap, tarif proporsional, tarif progresif, dan tarif degresif. ${ }^{3}$ Tarif berdasarkan jenis pajak salah satunya pada pemungutannya, maka Pajak Daerah merupakan pajak yang dipungut oleh Pemerintah Daerah (Provinsi, Kota, dan Kabupaten) yang merupakan salah satu sumber dari pendapatan asli daerah dan digunakan sebagai pembiayaan belanja daerah. Pemerintah Daerah yang diwakili oleh Dinas Pendapatan Daerah serta aparatur negara lainnya seperti Sistem Administrasi Manunggal Satu Atap (Samsat), ${ }^{4}$ yang diatur dalam Undang-Undang Nomor 28 Tahun 2009 tentang Pajak Daerah dan Retribusi Daerah.

Pasal 1 ayat (10) Undang-Undang Nomor 28 Tahun 2009 menjelaskan bahwa Pajak Daerah yang selanjutnya disebut Pajak, adalah kontribusi wajib pajak kepada Daerah yang terutang oleh orang pribadi atau badan yang bersifat memaksa berdasarkan Undang-Undang, dengan tidak mendapatkan imbalan secara langsung dan digunakan untuk keperluan Daerah bagi sebesar-besarnya kemakmuran rakyat

Mengarah pada pengaturan daerah, maka pembahasan tersebut mengenai ruang lingkup dari pajak pariwisata. Pajak Pariwisata merupakan sumber penerimaan pajak yang bersumber dari pajak kabupaten/kota. Pajak Daerah yang diatur UndangUndang Nomor 28 Tahun 2009 mengatur sumber-sumber penerimaan daerah yang merupakan kewenangan penuh oleh daerah. Dalam pembagian jenis pajak yang dikelompokan berdasarkan provinsi dan kabupaten/kota, maka pengembangan pada pariwisata terkait erat dengan pemungutan pajak dan retribusi daerah, terutama

\footnotetext{
${ }^{3}$ Marihot Pahala Siahaan, Op.Cit.[145].

${ }^{4}$ Roristua Pandiangan, Hukum Pajak (Graha Ilmu 2015).[40].
} 
pajak hotel, pajak restoran, dan pajak hiburan. ${ }^{5}$ Dalam hal perkembangan terhadap pariwisata maka dapat berdampak pada peningkatan penerimaan daerah, maka itu dapat memperbesar kemampuan dari daerah dalam meningkatkan kesejahteraan masyarakat. Maka demikan pajak pariwisata diharapkan dapat meningkatkan pendapatan asli daerah.

Anggaran Pendapatan dan Belanja Daerah atau yang sering disebutAPBN dapat dimanfaatkan oleh pemerintah Daerah yang didapatkan dari anggaran pendapatan asli daerah. Pendapatan asli daerah mempresentasikan kemandirian daerah dalam mengelola serta menemukan potensi pendapatan sesuai dengan sistem otonomi daerah yang tidak hanya diukur dari jumlah pendapatan daerah yang tercapai, melainkan sejauh mana pajak yang dipungut dapat meningkatkan kesejahteraan masyarakat di daerah. ${ }^{6}$ Maka perintah daerah diberi kewenangan untuk mengatur daerahnya supaya memeliki kemampuan dalam menyediakan dan menggali potensi yang ada. Dengan memanfaatkan potensi dan peluang dari pariwisata yang menjadi industri, diharapkan mampu meningkatkan pendapatan asli daerah sebagai sumber pembiayaan pembangunan daerah melalui pajak yang diterimanya. Pemerintah juga wajib merencanakan terhadap pariwisata yang memenuhi tujuan pembangunan pariwisata. Pembangunan pariwisata pada umumnya dilakukan oleh sektor swasta untuk pembangunan fasilitas serta jasa terhadap pariwisata. Tetapi jiku untuk pembangunan infrastruktur umum terhadap pariwisata maka itu merupakan tanggung jawab pemerintah. Kebijakan pariwisata Indonesia dimasukkan ke dalam kebijakan ekomoni secara keseluruhan yang kebijakan tersebut mencakup struktur dan pertumbuhan ekonomi jangka panjang.

Sektor pariwisata dalam perekonomian, dapat menyatukan aktivitas para wisatawan. Wisatawan yang datang ke Indonesia akan menghabiskan sejumlah

\footnotetext{
${ }^{5}$ Surtan Siahaan 'Analisis Sektor Pariwisata dan Dampaknya Terhadap Kemandirian Fiskal Daerah' (Badan Kebijakan Fiskal,2015) <https://fiskal.kemenkeu.go.id/kaji an/2015/06/22/095654002648760-analisis-sektor-pariwisata-dan-dampaknya-terhadapkemandirian-fiskal-daerah>, accessed 6 Februari 2020.

${ }^{6}$ Rieke Sri Rizki Asti Karini dan Indah Nur Agustiani, 'Kontribusi Penerimaan Pendapatan Sektor Pariwisata Terhadap Pnedapatan Asli Daerah (PAD) Kota Bandung', (2018) 4 Tourism Selentifie Journal.[92].
} 
uang, dari pengeluaran transportasi hingga membeli buah tangan pada daerah yang dituju sebagai tempat pariwisata. Hal ini akan mendapat menghasilkan efek secara langsung, karena dari pembisnis serta ekonomi yang dapat diukur juga terhadap pendapatan dari tenaga kerja pada sektor pariwisata tersebut, dan pajak yang dibayar oleh perusahaan pariwisata ke negara. Pada aspek ekonomi yang dipunyai sektor pariwisata berhubungan juga dengan kegiatan ekonomi yang langsung terhadap kegiatan pariwisata, seperti usaha perhotelan, restoran hingga penyelenggaraan paket wisata. Pada perekonomian negara, jika dikembangkan secara berencana dan matang maka peranan dari pariwisata tersebut akan melebihi dari sektor migas serta juga industry lainnya.

\section{Ratio Legis Terhadap Pemungutan Pajak Pariwisata Dalam Rangka Kebijakan} Indonesian Tourism

Indonesia menyimpan berjuta pesona wisata alam yang begitu indah dan Indonesia juga kaya dengan sumber daya alamnya, salah satunya ialah kepariwisataan yang terdapat di Indonesia. Kepariwiwsataan menurut Pasal 1 ayat (4) UndangUndang Nomor 10 Tahun 2009 tentang Kepariwisataan yaitu kepariwisataan merupakan keseluruhan kegiatan yang terkait dengan kepariwisataan dan bersifat multidimensi serta interaksi antara wisatawan dan masyarakat setempat, sesama wisatawan, Pemerintah, Pemerintah Daerah, serta pengusaha. Di Indonesia banyak destinasi yang mulai untuk meningkatkan kunjungan wisatawan, dengan memulai penerapan strategi pemasaran sebagai salah satu alternatif pemasukan kepada daerah sebagai pendapatan daerah ataupun devisa negara. Maka dengan tersedianya strategi pemasaran yang bagus dan tersusun secara sistematis, hal ini dapat membantu destinasi supaya lebih dikenal oleh seluruh masyarakat khususnya wisatawan mancanegara.

Melakukan pembangunan dalam pariwisata dapat dilakukan dari desa wisata, hal tersebut meupakan salah satu potensi andalan pariwisata di Indonesia, karena sebagian besar keindahan Indonesia berada pada kaasan pedesaan, kawasan hutan dan kawasan pegunungan. Maka itu, wisatawan mancanegara yang hadir dapat 
merasakan seperti berada di negara nya sendiri atau dapat bisa berada di rumah mereka sendiri dengan membutuhkan suatu peranan community atau tourism society yaitu komunitas selaku obyek serta pelaku usaha yang terlibat langsung dalam keseharian bertransaksi melaksanakan fungsi pelaksanaan, membangun komunikasi yang memungkinkan terwujudnya kondisi yang aman dan membuat wisatawan menikmati perjalan travelling mereka yang menyenangkan.

Dengan pertumbuhan sektor pariwisata yang terus meningkat, maka sangat terkait juga dengan adanya pengembangan infrastruktur yang hal itu menjadi sangat penting, karena akan mendorong perkembangan sektor pariwisata, sebab jika tidak adanya infrastruktur yang sesuai, maka akses untuk menuju tempat pariwisata akan rumit, sehingga mengakibatkan wisatawan akan jarang berkunjung ke tempat wisata. Dalam melaksanakan pembangunan, maka negara membutuhkan biaya yang dapat diperoleh dari penerimaan pajak. Maka terdapat pajak dari pariwisata, yang mana memiliki pernanan dalam meningkatkan pendapatan daerah. Dari sektor pariwisata dapat diharapkan untuk meningkatkan pendapatan asli daerah.

Pajak daerah mempunyai fungsi utama yaitu untuk mengisi kas daerah. Fungsi ini disebut fungsi budgetair yang sederhananya dapat diartikan sebagai alat pemerintah daerah, untuk menghimpun dana dari masyarakat untuk berbagai kepentingan dalam pembiayaan pembangunan daerah. Fungsi budgetair juga tercermin dalam prinsip efisiensi yang menghendaki pemasukan sebesar-besarnya dengan pengeluaran yang sekecil-kecilnya dari suatu penyelenggaraan pemungutan pajak daerah. Pajak daerah juga mempunyai fungsi lain yakni untuk mengatur atau regulatory. Pajak daerah dapat digunakan oleh pemerintah daerah sebagai instrument untuk mencapai tujuan tertentu. Dalam pengenaan pajak daerah dapat dilakukan untuk mempengaruhi tingkat konsumsi terhadap barang maupun jasa tertentu.

Sama halnya pada pariwisata, pemerintahan dapat melakukan pemungutan pajak pada sektor pariwisata, yakni seperti hotel, restoran, hingga tempat hiburan yang dikunjungi oleh wisatawan yang datang untuk menghabiskan sejumlah uangnya, seperti dari pengeluaran untuk transportasi hingga membeli produk semacam buah tangan di daerah wisata tersebut. Karena jika semakin meningkatnya 
pariwisata, maka akan berpengaruh terhadap meningkatnya industri hotel serta restoran, dikarenakan selama berpariwisata tentu wisatawan akan menginap di hotel untuk beristirahat serta membeli makanan atau minuman di restoran. Hal tersebut dapat menghasilkan efek secara langsung pada bisnis serta ekonomi yang dapat diukur dari pendapatan upah tenaga kerja pada sektor pariwisata dan pajak yang dibayar oleh perusahaan pariwisata ke negara.

Pada dasarnya Undang-Undang Pajak Penghasilan telah menetapkan sistem secara SelfAssesment. Sehingga terkait dengan pemungutan pajak hotel dan restoran menggunakan sistem Self Assesment. Karena dalam melakukan pembayaran pajak hotel dan pajak restoran tersebut, wajib pajak diberikan wewenang untuk menghitung, memperhitungkan, membayar, dan melaporkan besaran pajaknya ke Kantor Pelayanan Pajak (KPP) atau dapat melalui sistem administrasi yang dibuat oleh pemerintah secara online.

Dalam waktu bersamaan, sektor pariwisata juga berkontribusi terhadap Peningkatan Domestik Bruto, atau dapat disingkat PDB. Hal ini disebabkan karena sebagai pemicu banyaknya pendapatan devisa dan tentunya menyediakan kesempatan kerja untuk masyarakat Indonesia. PDB merupakan total nilai pasar dari keseluruhan barang maupun jasa yang diproduksi dalam perekonomian domestik semala periode tertentu. Sebagai alternatif, PDB dapat dijadikan sebagai jumlah pengeluaran atau total pendapatan dalam perekonomian, ${ }^{7}$ serta dapat dijadikan sebagai alat ukur dari pertumbuhan ekonomi suatu negara dan dapat dikatakan sebagai indikator ekonomi suatu negara untuk mengukur jumlah keseluruhan nilai produksi yang jumlah total tersebut dihasilkan oleh semua orang atau perusahaan, baik yang dimiliki oleh lokal ataupun asing disuatu negara.

Untuk mengenai pemungutan pajak terhadap pariwisata, sampai saat ini belum ada peraturan perundang-undangan yang mengatur secara jelas terhadap

7 Surtan Siahaan 'Kajian Dampak Sektor Pariwisata Terhadap Perekonomian Indonesia' (Kementerian Pariwisata dan Ekonomi Kreatif, 2019) < https://www.kemenparekraf.go.id/index. $\mathrm{php} /$ post/kajian-dampak-sektor-pariwisata-terhadap-perekonomian-indonesia $>$ accessed 19 Mei 2020. 
pemungutan pajaknya. Pada ruang lingkup pajak daerah yang terdiri dari pajak hotel, pajak restoran, pajak hiburan, pajak reklame, pajak penerangan jalan, pajak mineral bukan logam dan batuan, pajak parkir, pajak air tanah, hingga pajak sarang burung walet sudah diatur dalam Undang-Undang Nomor 28 Tahun 2009. Dalam sektor pariwisata mempunyai ruang lingkup yang melakukan pemungutan pajak serta retribusi daerah yakni dari pajak hotel, pajak restoran, dan pajak hiburan yang sudah tertulis dalam Undang-Undang Nomor 28 Tahun 2009. Sedangkan alam Undang-Undang Nomor 10 Tahun 2009 tentang Kepariwisataan tidak membahas mengenai pengaturan pajak terhadap pariwisata.

Dalam suatu pariwisata banyak pelaku yang terlibat. Meskipun peran mereka berbeda-beda, tetapi harus diperhitungkan dalam pengembangan pariwisata yaitu seperti industri pariwisata yang semua usaha wisata yang meghasilkan barang dan jasa bagi pariwisata. Industri pariwisata dapat dibedakan menjadi pelaku langsung yaitu usaha-usaha wisata yang menawarkan jasa secara langsung kepada wisatawan. Contoh hotel, restoran, biro perjalanan, pusat informasi wisata dan atraksi hiburan. Dan pelaku tidak langsung yaitu; usaha yang mengkhususkan diri pada produkproduk yang secara tidak langsung mendukung pariwisata. Contoh usaha kerajinan tangan, lembar panduan wisata dan sebagainnya.

Dengan menyelenggarakan suatu usaha terhadap pariwisata, maka pelaku usaha wajib melakukan pendaftaran terlebih dahulu unutk mendapatkan Tanda Datar Usaha Pariwisata yang diajukan ke Perangkat Daerah melalui Pelaana Terpadu Satu Pintu. Maka lokasi usaha pariwisata harus meliputi usaha daya tarik wisata, kawasan pariwisata, jasa makanan dan minuman, penyediaan akomodasi, penyelenggaraan kegiatan hiburan dan rekreasi. ${ }^{8}$

Namun salah satu unsur perhitungan pajak yang menentukan besarannya pajak terutang yang haus dibayar oleh Wajib Pajak ialah tarif pajak yang berlaku pada tiap jenis pajak daerah. Berkaitan dengan pemberian kewenangan dalam penerapan tarif, untuk menghindari penetapan tarif pajak yang tinggi serta dapat

${ }^{8}$ Ageng Prabandaru, 'Usaha Pariwisata dan Pembayaran Pajak yang Dikenakan' (Klik Pajak, 2018) <https://klikpajak.id/berita-pajak/pajak-usaha-pariwisata/> accessed 17 Juli 2020. 
menambahkan beban bagi masyarakat secara berlebihan, maka daerah hanya diberikan kewenangan untuk menetapkan tarif pajak dalam batas maksimum yang ditetapkan oleh Undang-Undang. Maka dari itu, untuk meningkatkan akuntabilitas bahwa sebagian hasil penerimaan pajak dialokasikan untuk membiayai kegiatan yang berkaitan dengan pajak tersebut. Tarif pajak merupakan dasar dari pengenaan pajak terhadap objek pajak yang menjadi tanggungannya. Presentasi (\%) merupakan bentuk dari tarif pajak, nilai yang berupa uang dijadikan untuk menghitung pajak terutang merupakan dasar dari pengenaan pajak.

Dalam sektor pariwisata mempunyai ruang lingkup yang melakukan pemungutan pajak serta retribusi daerah yakni dari pajak hotel, pajak restoran, dan pajak hiburan. Pajak hotel merupakan pajak atas pelayanan yang diberikan oleh hotel. Pasal 1 ayat (21) Undang-Undang Nomor 28 Tahun 2009 menjelaskan bahwa hotel merupakan fasilitas yang menyediakan jasa penginapan atau peristirahatan, dengan dipungut bayaran, yang mencakup seperti wisma pariwisata, losmen, motel, gubuk pariwisata, serta rumah kos dengan jumlah kamar lebih dari 10. Besaran atas pajak terhadap hotel ditentukan oleh variable tetap yang berdasarkan kelas atas hotel yang ditempati, serta jumlah yang dikenakan perhari dan perorang, maka mata rantai pada pariwisata yang seperti hotel ataupun penginapan, restoran atau tempat makan, serta berbagai macam hiburan serta usaha perjalan wisata dapat menjadikan sumber penerimaan daerah yang berupa pajak daerah.

Dalam suatu pariwisata banyak pelaku yang terlibat. Meskipun peran mereka berbeda-beda, tetapi harus diperhitungkan dalam pengembangan pariwisata yaitu seperti industri pariwisata yang semua usaha wisata yang meghasilkan barang dan jasa bagi pariwisata. Industri pariwisata dapat dibedakan menjadi pelaku langsung yaitu usaha-usaha wisata yang menawarkan jasa secara langsung kepada wisatawan. Contoh hotel, restoran, biro perjalanan, pusat informasi wisata dan atraksi hiburan. Dan pelaku tidak langsung yaitu; usaha yang mengkhususkan diri pada produkproduk yang secara tidak langsung mendukung pariwisata. Contoh usaha kerajinan tangan, lembar panduan wisata dan sebagainnya. 
Dengan menyelenggarakan suatu usaha terhadap pariwisata, maka pelaku usaha wajib melakukan pendaftaran terlebih dahulu unutk mendapatkan Tanda Datar Usaha Pariwisata yang diajukan ke Perangkat Daerah melalui Pelaana Terpadu Satu Pintu. Maka lokasi usaha pariwisata harus meliputi usaha daya tarik wisata, kawasan pariwisata, jasa makanan dan minuman, penyediaan akomodasi, penyelenggaraan kegiatan hiburan dan rekreasi. ${ }^{9}$ Dalam melakukan kegiatan usaha pariwisata yang temasuk objek pajak yang dikenakan Pajak Daeah tentunya pengusaha wajib mendaftarkan izin usahanya ke Perangkat Daerah untuk mendapatkan Nomor Pokok Wajib Pajak Daerah. Pelaku usaha dari pengusaha pariwisata wajib membayar kewajiban Pajak Daerah sesuai dengan ketentuan peraturan perundang-undangan yaitu sebesar $10 \%$ dari penghasilan yang diperoleh dalam sebulan.

\section{Penegakan Hukum Terhadap Pelanggaran Pajak Pariwisata Dalam Rangka Kebijakan Indonesian Tourism}

Dalam setiap pemungutan pajak terhadap setiap bidangnya, maka harus ditingkatkan dan memiliki penegakan hukum agar tidak terjadi kebocoran pada berbagai sumber serta penerimaan pajak dirasakan maksimal. Fungsi dari penegakan hukum yaitu sebagai perlindungan kepentingan bagi manusia. Pelaksanaan hukum dapat berlangsung normal serta damai, tetapi dapat juga terjadi pelanggaran hukum. Maka hal ini, hukum yang telah dilanggar harus ditegakan, melalui pengekan hukum inilah hukum menjadi kenyataan. Dalam penegakan hukum terdapat 3 unsur yang harus diperhatikan, yaitu kepastian hukum, keadilan, serta pemanfaatan hukum. Pada pemungutan pajak terdapat beberapa pihak yaitu wajib pajak, pemungutan pajak, serta pihak ketiga yang terlibat dalam perpajakan. Maka hukum pajak merupakan ranah hukum publik yang termasuk dalam hukum administrasi. Penegakan hukum pajak bermakna sebagai langka bagaimana menegakan suatu norma hukum yang terdapat dalam Undang-Undang Pajak. Undang-Undang Nomor 28 Tahun 2007 tentang Ketentuan Umum Dan Tata Cara Perpajakan menjelaskan

9 Ageng Prabandaru, 'Usaha Pariwisata dan Pembayaran Pajak yang Dikenakan' (Klik Pajak, 2018) <https://klikpajak.id/berita-pajak/pajak-usaha-pariwisata/> accessed 17 Juli 2020. 
bahwa hukum administrasi yang memuat sanksi pidana, bahwa dalam UndangUndang Nomor 28 Tahun 2007 terdapat 2 jenis sanksi terhadap pajak, yaitu sanksi administrasi serta sanksi pidana.

Sanksi administrasi merupakan suatu tindakan yang diberikan kepada Wajib Pajak yang tidak memenuhi kewajibannya dalam menjalankan suatu kewajiban dalam perpajakannya. Sanksi administrasi yang diberikan kepada Wajib Pajak bertujuan agar masyarakat, Wajib Pajak, petugas ataupun aparatur perpajakan agar mematuhi kewajibannya. Sanksi administrasi perpajakan terdiri dari sanksi denda, sanksi bunga serta sanksi kenaikan.

Kepariwisataan juga mempunyai sanksi yang ditujukan kepada wisatawan serta pengusaha pariwisata. Wisatawan yang tidak menjaga dan menghormati norma agama, adat istiadat, dan nilai-nilai kehidupan, seta memelihara dan melestarikan lingkungan, turut serta menjaga ketertiban dan keamanan lingkungan, dan turut serta mencegah segala bentuk perbuatan yang melanggaran kesusilaan dan kegiatan yang melanggar hukum, akan dikenakan Pasal 62 ayat (1) yaitu sanksi berupa teguran lisan yang diserai dengan pemberitahuan mengenai hal yang harus dipenuh, dan jika teguran tersebut tidak diindahkan sebagai mana Pasal 62 ayat (2) menjelaskan, maka wisatawan yang bersangkutan dapat diusir dari lokasi perbuatan yang dilakukan.

Pengusaha pariwisata akan dikenakan sanksi administrasi jika Pasal 15 ayat (1) tidak terpenuhi, pengusaha pariwisata diwajibkan mendaftarkan usahanya terlebih dahulu kepada Pemerintah Daerah. Maka sanksi administratif yang diberikan kepada pengusaha pariwisata menurut Pasal 62 ayat (2) yaitu berupa, teguran tertulis sebanyak 3 kali, adanya pembatasan usaha, pembekuan sementara terhadap kegiatan usaha.

Meskipun sifat dari sanksi administrasi adalah memaksa, namun pejabat yang memiliki kewenangan untuk menangani pajak pusat ataupun pajak daerah dilarang untuk melakukan tindakan yang sewenang-wenang kepada wajib pajak, karena tujuan dari pengenaan sanksi administrasi yaitu tidak untuk menghukum, melainkan untuk mengingatkan kepada Wajib Pajak supaya patuh terhadap pelaksanaan kewajiban pajak. 
Dalam melaksanakan kewajibannya untuk membayar pajak, maka Wajib Pajak harus jujur sebab apabila Wajib Pajak tidak melaksakan kewajibannya maka pihak yang melanggar akan terkena sanksi pidana. Dalam sanksi pidana dapat berupa sanksi denda pajak atau yang berakibat terhadap hukuman badan yaitu seperti denda pidana, pidana kurungan, serta pidana penjara: ${ }^{10}$

a. Denda Pidana

Sanksi tersebut dikenakan kepada Wajib Pajak maupun pihak ketiga yang melakukan pelanggaran norma.

b. Pidana Kurungan

Sanksi tersebut berupa perampasan kebabasan terhadap Wajib Pajak serta pihak ketiga yang melakukan pelanggaran peraturan perpajakan.

c. Pidana Penjara

Sanksi tersebut berupa perampasan kebebasan yang melakukan pelanggaran yang bisa dipenjara selama bertahun-tahun hingga seumur hidup.

Berdasarkan Pasal 37 Undang-Undang Nomor 28 Tahun 2009 Pasal 174 ayat (1) tentang Pajak Daerah dan Retribusi Daerah, menyetakan jika Wajib Pajak karena kealpaannya tidak menyampaikan SPTPD atau mengisi dengan tidak benar atau tidak lengkap atau melampirkan yang tidak benar sehingga dapat merugikan keuangan daerah maka dapat dipidana dengan pidana kurungan paling lama 1 tahun dan denda paling banyak 2 kali jumlah pajak terutang. Jika Pasal 174 ayat (2) menjelaskan bahwa Wajib Pajak karena sengaja tidak menyampaikan SPTPD sama halnya dengan Pasal 174 ayat (1) maka dapat dipidana dengan pidana penjara paling lama tahun atau pidana denda paling banyak 4 kali jumlah pajak terutang.

Jika terjadi suatu sengketa pajak, maka pada awalnya akan diterbitkan surat ketetapan pajak atau yang dapat disebut surat tindakan penagihan pajak. Sengketa pajak menurut Pasal 1 ayat (5) Undang-Undang Nomor 14 Tahun 2002 tentang

${ }^{10}$ Surtan Siahaan, 'Penyebab Seseorang Dijatuhkan Sanksi Pidana Pajak' (Online Pajak, $2018)<$ https://www.online-pajak.com/sanksi-pidana-pajak\#: :text=Sanksi\%20pidana\%20 pajak $\% 20$ adalah $\% 20$ jenis,badan $\% 20$ seperti\%20penjara\%20atau\%20kurungan.> accessed 15 Juni 2020 . 
Pengadilan Pajak yaitu, sengketa yang timbul dalam bidang perpajakan antara Wajib Pajak atau penanggung Pajak dengan pejabat yang berwenang sebagai akibat dikeluarkannya keputusan yang dapat diajukan Banding atau Gugatan kepada Pengadilan Pajak berdasarkan peraturan perundang-undangan perpajakan, termasuk Gugatan atas pelaksanaan penagihan berdasarkan Undang-Undang Penagihan Pajak dengan Surat Paksa.

Timbulnya sengketa juga dapat disebabkan adanya pemungutan yang dilakukan oleh pihak ketiga berdasarkan ketentuan Undang-Undang. Maka upaya hukum untuk menyelesaikan terjadinya sengketa yang dapat dilakuakn oleh Wajib Pajak adalah keberatan, banding, peninjauan kembali dan gugatan. Dalam melakukan upaya hukum keberatan atas penetapan pajak dapat diajukan ke Direktorat Jenderal Pajak, sedangkan upaya hukum banding dan gugatan dapat diajukan ke Pengadilan Pajak, namun untuk upaya hukum Peninjauan Kembali dapat diajukan ke Mahkamah Agung.

Penegakan hukum preventif merupakan penegakan hukum yang dilakukan sebelumnya adanya pelanggaran bertujuan untuk mencegah terjadinya sengketa yang dilakukan oleh Wajib Pajak. Upaya dalam penegakan hukum preventif yang dilakukan oleh pemerintah, dan supaya tidak terjadinya pelanggaran yang dilakukan oleh Wajib Pajak yaitu dengan cara memberikan seminar, pelatihan, serta sosialisasi teradap Wajib Pajak sehingga dapat meminimalisir terjadinya kealpaan dari Wajib Pajak dalam melaksanakan pembayaran pajak, serta juga mengurangi terjadinya kecurangan yang dilakukan terhadap Wajib Pajak. Sehingga dengan diadakan kegiatan tersebut secara langsung seperti seminar, pelatihan serta sosialisasi, maka Wajib Pajak yang belum mengetahui informasi terbaru mengenai pajak menjadi mengetahui terkait informasi terbaru, sehingga hal tersebut dapat menekan terjadinya kerugian Negara yang timbulkan dari kealpaan Wajib Pajak. ${ }^{11}$

Pemungutan pajak pada sektor pariwisata, maka Wajib Pajak dituntut kesadarannya untuk membayar pajak tepat waktu dengan jumlah yang sesuai

${ }^{11}$ Izzan Razaka Praditama, Op.Cit.[516]. 
dengan data transaksi usaha. Terkait dengan kepatuhan Wajib Pajak yang dituntut kesadarannya untuk membayar pajak, maka perlu pengawasan untuk menentukan ataupun mengevaluasi pelaksanaan pemungutan pajak yang sudah dilaksakan, serta mengetahui pelaksanaan kebijakan terhadap perpajakan serta melihat penyimpangan yang terjadi pada saat pelaksanaan pemungutan pajak.

Penegakan hukum represif bertujuan untuk menyelesaikan suatu sengketa ataupun pelanggaran pajak yang telah dilakukan oleh Wajib Pajak. Apabila terjadi sengketa atau pelanggaran terhadap pajak, maka dapat diselesaikan melalui pengadilan. Penegakan hukum represif yang telah dilakukan oleh Wajib Pajak dengan menetapkan sanksi berupa sanksi administrasi ataupun sanksi pidana, hal ini bertujuan untuk memberi efek jera terhadap Wajib Pajak serta sebagai pengingat bagi Wajib Pajak untuk memenuhi kewajibannya dalam melakukan pembayaran pajak. ${ }^{12}$

Terkait dengan Wajib Pajak pada sektor pariwisata dalam penegakan represif, bagi Wajib Pajak yang tidak membayarkan pajaknya dengan tepat waktu atau jumlah pajak yang tidak sesuai dengan data serta pelaporan SPTPD, maka Pemerintah Daerah dapat melaksakan penegakan hukum bagi Wajib Pajak pada sektor pariwisata yaitu hotel, restoran, dan hiburan berdasarkan Undang-Undang Nomor 28 Tahun 2009 tentang Pajak Daerah dan Retribusi Daerah, serta UndangUndang Nomor 28 Tahun 2007 tentang Ketentuan Umum dan Tata Cara Perpajakan.

\section{Kesimpulan}

Pajak pariwisata merupakan penerimaan pajak yang berasal dari kabupaten/ kota, yakni pajak yang berasal dari pajak hotel, pajak restoran, serta pajak hiburan. Dari sektor pariwisata diharapkan dapat meningkatkan dan menjadi penunjang pendapatan daerah. Dengan pendapatan daerah yang diperoleh dari pajak, maka secara otomatis dapat mendorong perkembangan pariwisata secara pesat seperti dalam hal melakukan beberapa pembangunan fasilitas daerah yang dapat digunakan dan menjadi penunjang untuk masyarakat. Terkait dalam pengenaan Pajak

${ }_{12}$ Irwansyah Lubis, Abidah Sari Lubis, Muhammad Zuhdi Lubis, Taat Hukum Pajak (Mitra Wacana Media 2018).[77]. 
Penghasilan dan Pajak Daerah, tetap dikenakan oleh hotel namun restoran hanya dipungut oleh Pemerintah Daerah, karena pada setiap orang yang makan di restoran akan dikenakan pajak daerah.

Pemungutan pajak dalam sektor pariwisata terdapat beberapa pihak yaitu wajib pajak, pemungutan pajak, serta pihak ketiga yang terlibat dalam perpajakan. Dalam Undang-Undang Nomor 28 Tahun 2007 terdapat dua jenis sanksi terhadap pajak, yaitu sanksi administrasi serta sanksi pidana. Terkait pemungutan pajak pada sektor pariwisata, maka Wajib Pajak dituntut kesadarannya untuk membayar pajak tepat waktu dengan jumlah yang sesuai dengan data transaksi usaha. Jika terjadi suatu sengketa pajak, maka akan diterbitkan surat ketetapan pajak atau yang dapat disebut surat tindakan penagihan pajak. Maka upaya hukum untuk menyelesaikan terjadinya sengketa yang dapat dilakuakn oleh Wajib Pajak adalah keberatan, banding, peninjauan kembali dan gugatan.

\section{Daftar Bacaan}

\section{Buku}

Erly Suandy, Hukum Pajak (Salemba Empat 2008).

Irwansyah Lubis, Abidah Sari Lubis, Muhammad Zuhdi Lubis, Taat Hukum Pajak (Mitra Wacana Media 2018).

Marihot Pahala Siahaan, Hukum Pajak Elementer (Graha Ilmu 2010).

Roristua Pandiangan, Hukum Pajak (Graha Ilmu 2015).

\section{Jurnal}

Rieke Sri Rizki Asti Karini dan Indah Nur Agustiani, 'Kontribusi Penerimaan Pendapatan Sektor Pariwisata Terhadap Pnedapatan Asli Daerah (PAD) Kota Bandung', (2018) 4 Tourism Selentifie Journal.

\section{Laman}

Ageng Prabandaru, 'Usaha Pariwisata dan Pembayaran Pajak yang Dikenakan'(Klik Pajak, 2018) <https://klikpajak.id/berita-pajak/pajak-usaha-pariwisata/>. 
Surtan Siahaan, 'Penyebab Seseorang Dijatuhkan Sanksi Pidana Pajak' (Online Pajak, 2018) <https://www.online-pajak.com/sanksi-pidana pajak\#: :text=Sanksi\%20pidana\%20pajak\%20adalah\%20jenis,badan\%20s eperti\%20penjara\%20atau\%20kurungan.>.

'Analisis Sektor Pariwisata dan Dampaknya Terhadap Kemandirian Fiskal Daerah' (Badan Kebijakan Fiskal,2015) < h t t p s : / / f i s k a 1. k e m e n k e u.g o.i d / kajian/2015/06/22/095654002648760- analisis-sektor-pariwisata-dandampaknya-terhadap-kemandirian-fiskal- daerah>.

'Kajian Dampak Sektor Pariwisata Terhadap Perekonomian Indonesia' (Kementerian Pariwisata dan Ekonomi Kreatif, 2019) <https://www.kemenparekraf.go.id/index.php/post/kajian-dampaksektor- pariwisata-terhadap-perekonomian-indonesia $>$. 